\title{
KONJUNGSI KLAUSA OBJEK DALAM KALIMAT SUBORDINATIF BAHASA INDONESIA
}

\author{
Hasnah Faizah AR \\ Fakultas Keguruan dan Ilmu Pendidikan Universitas Riau \\ Jl. Binawidya KM 12,5 Simpang Panam Pekanbaru-Riau, Indonesia 28293 \\ e-mail: hasnahhfaizahar @yahooo.com
}

\begin{abstract}
ABSTRAK. Pokok persoalan yang dikaji dalam penelitian ini adalah klausa objek sebagai konstruksi subordinatif dalam BI berdasarkan analisi struktur dan semantik. Hal ini terlihat dari bentuk dan maknanya. Bahasa yang diteliti adalah bahasa Indonesia (BI) dalam bentuk tulisan, khususnya data tertulis beberapa tulisan ilmiah seperti, jurnal ilmiah, buku ilmiah, dan laporan ilmiah (disertasi, tesis, dan skripsi). Penelitian ini menggunakan metode distribusional (agih) dengan menggunakan empat macam teknik analisis data: teknik sulih, sisip, lesap, dan pindah unsur. Konjungsi yang menyertai klausa objek dibedakan menjadi konjungsi monomorfemis adalah bahwa, mengapa, bagaimana, apakah, kapan, agar, supaya, untuk, betapa, dan konjungsi polimorfemis adalah ke mana, sejauh mana, di mana, dari mana, kepada siapa, untuk siapa, dengan siapa, dengan apa, untuk apa, sambil apa, waktu apa, sehabis apa, sejak kapam dan berapa lama.
\end{abstract}

Kata kunci: Konjungsi, subordinatif, klausa, dan objek

\section{THE CONJUCTIONS OF THE OBJECT CLAUSE IN THE INDONESIAN SUBORDINATIVE SENTENCES}

\begin{abstract}
The aim of this research is to analyze the structure and semantic conjunction behavior of the object clause as subordinative construction in Indonesian. It is seen from the forms and meanings. This is a written Indonesian study, especially scientific writing. The source of the data is from scientific journals, scientific books, scientific reports (dissertations, theses, and academic essays). This study uses distributional method with four techniques: substitution, interruption, permutation, and deletion. The conjunction used in these constructions are divided into monomorphemic and polimorphemic conjunctions. The monomorphemic conjunctions are bahwa, bagaimana, kapan, agar, supaya, untuk, and betapa. The polimorphemic conjunctions are ke mana, sejauh mana, bagaimanakah, apakah, mengapa, di mana, dari mana, kepada siapa, untuk siapa, dengan siapa, dengan apa, untuk apa, sambil apa, waktu apa, sehabis apa, sejak kapan, and berapa lama.
\end{abstract}

Key words: Conjunction, Subordinative, Clause, and Object 


\section{PENDAHULUAN}

Setiap bahasa memiliki konjungsi yang khas. Dengan kata lain, konjungsi suatu bahasa memiliki karakteristik yang berbeda jika dibandingkan dengan konjungsi bahasa lain. Kekhasan konjungsi suatu bahasa juga dapat dikaitkan dengan kebudayaan penutur bahasa tersebut karena konjungsi pada hakikatnya menghubungkan dua buah atau lebih unsur linguistik yang berisi buah pikiran dari penuturnya.

Konjungsi sebagai alat untuk menghubungkan satu unsur linguistik dengan unsur linguistik lainnya berhubungan dengan pikiran penuturnya karena unsurunsur linguistik yang dihubungkannya mengandung makna berupa konsep pikiran yang menghubungkan unsur-unsur linguistik sebagai simbol dengan acuan atau referen.

Hubungan itu sebagai gambar segitiga. Simbol adalah unsur linguistik yakni kata, frasa, klausa dan sebagainya. Acuan adalah objek yang terdapat dalam dunia pengalaman, sedangkan pikiran atau referen adalah konsep. Secara teoretis, tidak ada hubungan langsung antara simbol dengan acuan atau antara bahasa dengan dunia. Hubungan hanya melalui pikiran atau referensi yang merupakan konsep pikiran manusia. Lebih jelasnya, lihat gambar berikut.

Acuan

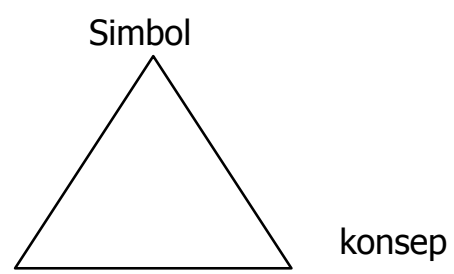

Di samping itu, untuk menghubungkan satu unsur linguistik dengan unsur linguistik lainnya, seseorang harus memperhatikan kelogisan pikiran yang terkandung dalam setiap unsur linguistik yang dihubungkannya sehingga tercipta kepaduan hubungan.

Konjungsi sering disebut dengan istilah kata penghubung (S. Zainudin GI. Png. Batuah, 1956:204-212; Lubis, 1950:66-69; Soetarno, 1976:167-169; Hadiwidhaya, 1965:95-97; Ramlan, 1980:18); partikel konektif (Moeliono, dalam Rusyana dan Samsuri, 1976 :105-106); kata perangkai/kata penghubung (Slametmuljana, 1955: 175; Zoetmulder dan Poedjawijatna, 1964:64); kata sambung (Mees, 1955:277-278; Suhendar, 1978:22-28); kata sambung atau conjunction (Keraf,1973:86; kata sambung/konjungtor (Alisjahbana, 1960:75); Konjungsi (Kridalaksana,1986:99; Moeliono, 1988:230; Gianto,1983:3; Chaer, 1987:5, 53). Istilah konjungsi ini dalam bahasa Inggris disebut conjunction (Hockett,1964:192-195; Bloomfield, 1933:198; Lyons, 1969:178; Gleitman, 1965:260) (Nardiati dkk.,1996:1)

Konjungsi termasuk dalam kata tugas di samping preposisi, interjeksi, artikula dan partikel penegas. Walaupun dalam kelas kata yang sama, preposisi dan konjungsi mempunyai perbedaan. Seperti yang dikemukakan oleh Sibarani (1994:49-54) bahwa konstruksi yang menggunakan konjungsi dapat dibuktikan dan dikenali menjadi dua klausa atau lebih, sedangkan konstruksi yang 
menggunakan preposisi tidak dapat dibuktikan atau dikenali menjadi dua klausa atau lebih. Di samping itu, konjungsi bisa mendahului preposisi, sedangkan preposisi tidak pernah bisa mendahului konjungsi, misalnya Dia merasa khawatir sebelum ke surabaya. (lihat Sobarna, 2003: 263). Dengan kata lain, sebuah unsur lingual disebut konjungsi apabila ia dapat diikuti oleh klausa atau dapat dibuktikan bahwa klausa tersebut dapat dimunculkan (lihat pula Tadjuddin, 2005:184). Contoh yang dikemukan Tadjuddin seperti berikut.

Contoh a. Ia tinggal bersama kami sejak dulu.

b. Ia tinggal bersama kami sedari dulu.

Pada kalimat (a) tampak bahwa unsur lingual sejak pada konstruksi tersebut adalah sebagai konjungsi. Namun, sedari pada (b) sebagai preposisi. Unsur lingual sejak disebut konjungsi karena konstruksi (a) dapat dimunculkan klausanya, misalnya Ia tinggal bersama kami sejak kedua orang tuanya meninggal dulu., sedangkan unsur lingual sedari disebut preposisi karena tidak dapat dimunculkan klausanya, misalnya * Ia tinggal bersama kami sedari kedua orang tuanya meninggal dunia. Selanjutnya penelitian ini menggunakan teori yang dikemukakan oleh Sibarani, Sobarna, dan Tadjuddin untuk menentukan konsep konjungsi.

Konjungsi subordinatif sebagai salah satu konjungtor atau kata sambung adalah kata tugas yang menghubungkan dua klausa atau lebih dan klausa itu tidak memiliki status sintaktis yang sama. Salah satu klausa itu merupakan anak kalimat.

Lapoliwa, (1990: 44) menyatakan bahwa klausa pemerlengkapan dalam BI dapat ditandai oleh kehadiran pemerlengkap, yaitu sejenis konjungsi yang berfungsi menghubungkan klausa pemerlengkapan dengan klausa matriks. Pemerlengkap dalam BI yang lazim digunakan dalam ragam baku adalah bahwa, supaya (=agar; agar supaya), dan untuk. Kata tanya dapat pula menjadi pemerlengkap, yaitu jika klausa pemerlengkapan itu berasal dari kalimat interogatif. Perlu dicatat bahwa dalam BI terdapat pula klausa pemerlengkapan yang dihubungkan langsung dengan matriks tanpa ada pemerlengkap yang mendahuluinya.

Pendapat yang senada juga dikemukakan oleh Sugono dan Indyastini (1994: 40-43) yang menyatakan bahwa komplementasi (=pemerlengkapan) yang berupa klausa dapat dihubungkan oleh agar, untuk, bahwa dan kata tanya apakah, apa, ke mana, di mana, dan sebagainya. Namun, pembahasan Lapoliwa dan Sugono dan Indyastini tersebut belum mengklasifikasikan fungsi sintaktis pada klausa sebagai komplementasi atau pemerlengkapan tersebut seperti dalam kalimat berikut.

a. Seorang tentara bercerita bahwa usaha ini dikontrol dan dilindungi Vietcong.

b. Kami tidak tahu bahwa salah seorang korban itu adalah kakak kandungnya.

c. Dia menanyakan apakah saya menyimpan ramuan kompres itu.

d. Dia selalu merahasiakan ke mana dia pergi.

Pada contoh di atas tampak bahwa klausa subordinatif dihubungkan oleh Konj bahwa, apakah, ke mana, dan di mana. Klausa subordinatif pada kalimat (a) 
bahwa usaha ini dikontrol dan dilindungi Vietcong berfungsi sebagai Pel karena didahului oleh Verba Taktransitif bercerita; klausa subordinatif pada kalimat (b) bahwa salah seorang korban itu adalah kakak kandungnya berfungsi sebagai $\mathrm{K}$ karena didahului oleh Verba transitif tidak tahu; sedangkan klausa subordinatif pada kalimat (c dan d) berfungsi sebagai $O$ karena didahului oleh verba menanyakan dan merahasiakan. Jadi, dapat dikemukakan bahwa fungsi sintaksis klausa subordinatif ( $\mathrm{O}$, Pel, atau $\mathrm{K}$ ) ditentukan oleh bentuk verba yang mendahuluinya.

Berdasarkan bentuknya, Konj subordinatif dapat diklasifikasikan menjadi tiga, yakni monomorfemis, polimorfemis, dan korelatif. Berdasarkan fungsinya, diklasifikasikan menjadi tiga pula, yakni koordinatif, subordinatif, dan kohesif. Berdasarkan maknanya diklasifikasikan menjadi empat macam, yakni aditif, adversatif, kausal, dan temporal. (lihat pula Sibarani, 1994:299).

Nardiati dkk. (1996:239) juga menyinggung tentang klausa subordinatif yang dihubungkan oleh konjungsi. Namun mereka sudah mengklasifikasikan fungsifungsi yang terdapat pada klausa subordinatif tersebut, bahkan mereka menyimpulkan bahwa berdasarkan fungsi sintaksisnya, klausa anak/klausa subordinatif pada kalimat majemuk bertingkat dapat menduduki fungsi K. Selain itu, klausa subordinatif pada kalimat majemuk bertingkat dapat menduduki fungsi O, S, dan Pel.

Sementara itu, Tadjuddin dkk. membagi Konj (Konjungsi) BI berdasarkan bentuknya menjadi dua kelompok, yaitu konjungsi monomorfemis dan polimorfemis. Konjungsi monomorfemis adalah konjungsi yang secara morfologis berwujud sebagai satu morfem, misalnya agar, bahkan, bahwa, buat, karena, mengenai, dan konjungsi polimorfemis adalah konjungsi yang terbentuk dari beberapa morfem, misalnya bagaikan, sebelum (bentuk dasar + afiks), akibatnya, artinya (kata + anafora), adapun, walaupun (kata + pun), untuk ini, karena itu (kata + demonstrativa), akan tetapi, begitu pula (gabungan kata), dalam pada itu, oleh sebab itu (gabungan kata + demonstrativa), dsb. (lihat pula Tadjuddin, dkk, 2001:52-57).

Alwi, dkk. (1998:410-411) menyatakan bahwa subordinator yang sering dipakai untuk menghubungkan klausa utama dengan klausa subordinatif adalah Konjungsi bahwa. Jika makna atau proposisi yang terkandung dalam klausa subordinatif berhubungan dengan ketidakpastian, pertanyaan, atau jawaban yang tersirat, klausa subordinatifnya berbentuk klausa tanya yang ditandai oleh (a) kata tanya seperti apa, siapa, mengapa, atau bagaimana, yang bisa diikuti oleh partikel - kah, atau (b) gabungan kata seperti dengan siapa, untuk apa atau ke mana. Bentuk-bentuk ini sekaligus sebagai penghubung klausa utama dan klausa subordinasi (lihat pula Djajasudarma, 1999: 29). Lebih lanjut Alwi, dkk menyatakan bahwa kalimat eksklamatif juga dapat menjadi klausa subordinatif sejenis itu. Misalnya, Dia telah membuktikan alangkah cantiknya gadis itu.

Selanjutnya, teori Lapoliwa, Sugono dan Idyastini, Sibarani, Alwi, dkk., Djajasudarma, dan Tadjuddin, dkk akan dipertimbangkan untuk menentukan jenis Konj yang menyertai KO dalam penelitian ini. Berdasarkan uraian teori di atas, dapat dipahami bahwa klausa subordinatif yang berfungsi sebagai $O$ bisa juga didahului oleh Konj bahwa, kata tanya (siapa(kah), apa(kah), mengapa(kah), 
bagaimana(kah), untuk, agar, supaya, alangkah atau betapa dengan syarat konjungsi tersebut harus didahului oleh verba aktif transitif. Jadi, apabila klausa subordinatif, baik disertai Konj atau tidak, jika didahului oleh verba aktif transitif, maka klausa subordinatif tersebut dapat dikatakan sebagai klausa yang berfungsi sebagai objek.

Konjungsi berfungsi menghubungkan dua buah unsur linguistik (konjoin) atau lebih untuk membentuk unsur linguistik (konstruksi) yang lebih kompleks. Kata yang dihubungkan dengan kata yang lain akan membentuk frasa atau langsung membentuk klausa atau kalimat; frasa yang dihubungkan dengan frasa yang lain akan membentuk frasa yang kompleks atau langsung membentuk klausa atau kalimat; klausa yang dihubungkan dengan klausa akan membentuk kalimat majemuk setara atau kalimat majemuk bertingkat; kalimat yang dihubungkan dengan kalimat akan membentuk penggalan wacana yang kohesif (Nardiati, dkk., 1996)

Konjungsi subordinatif dalam bahasa Indonesia merupakan salah satu jenis konjungsi yang berfungsi menghubungkan satuan lingual yang satu dengan satuan lingual yang lain yang tidak sederajat kedudukannya (Narditi, dkk., 1996:1).

Kehadiran konjungsi subordinatif dalam konstruksi sintaksis selalu berada dalam klausa terikat yang menduduki klausa anak pada sebuah kalimat. Keberadaannya pada sebuah konstruksi dapat berfungsi sebagai subjek (S), Predikat $(P)$, objek (O), pelengkap (Pel), dan keterangan (Ket)

Objek penelitian ini adalah berbagai jenis konjungsi subordinatif dalam bahasa Indonesia, khususnya, yang berfungsi menghubungkan klausa induk dengan klausa anak pada kalimat majemuk bertingkat yang klausanya berfungsi sebagai objek.

Dalam penelitian terdahulu, antara lain Keraf (1986), dan Sibarani (1994), menyatakan bahwa konjungsi berfungsi sebagai penghubung antarklausa yang satu dan klausa yang lain dalam kalimat luas. Adanya batasan ini memberikan pesan kepada pembaca bahwa konjungsi hanya dapat menghubungkan klausa yang satu dan klausa yang lain dalam sebuah kalimat luas. Pernyataan ini perlu dipertimbangkan, sebab dalam kenyataannya konjungsi dapat menghubungkan satuan lingual yang sedikitnya berupa kata atau kelompok kata dengan satuan lingual yang lain, baik itu berupa kata, frasa, klausa, klausa dengan klausa, kalimat dengan kalimat dan bahkan paragraf dengan paragraf.

Selanjutnya, dikatakan bahwa konjungsi yang selalu berposisi antara klausa disebut konjungsi yang setara, sedangkan konjungsi yang berkemungkinan terletak di antara klausa dan di awal klausa disebut konjungsi yang tidak setara. Terhadap pernyataan itu menurut penulis perlu ditinjau kembali sebab kenyataan menunjukkan bahwa ada klausa anak yang berkonjungsi subordinatif tertentu yang mempunyai posisi yang cukup tegar. Misalnya, klausa anak yang berkonjungsi $d i$ mana, bagai, bagaikan, baik, dari pada, dan sebagainya. Dengan diketahuinya kekurangan-kekurangan pada penelitian terdahulu seperti yang telah disebutkan di atas, penulis merasa terdorong untuk melakukan penelitian tentang kajian sintaksis konjungsi klausa objek dalam bahasa Indonesia

Berdasarkan latar belakang masalah yang telah dikemukakan di atas, perumusan masalah dalam penelitian ini adalah "konjungsi apa sajakah yang 
terdapat dalam klausa objek bahasa Indonesia?" Jadi, penelitian ini bertujuan mendeskripsikan jenis-jenis konjungsi yang terdapat pada klausa objek dalam bahasa Indonesia. Hal ini dilakukan karena walaupun masalah $\mathrm{O}$ sebagai salah satu fungsi sintaksis sudah sering dibicarakan dalam berbagai buku tata bahasa struktural, seperti buku yang ditulis oleh Kridalaksana dkk., (1985), Ramlan (1996), dan Alwi, dkk. (1998), namun pembicaraan masalah O pada ketiga buku tersebut masih berkisar pada struktur fungsional $O$ dalam kalimat yang terbatas pada kalimat tunggal ( $\mathrm{O}$ berupa klitik, kata, dan frasa). Bagaimana keberadaan $\mathrm{O}$ dalam kalimat kompleks, apalagi konjungsinya belum dibahas dalam tulisan tersebut.

\section{METODE PENELITIAN}

Metode adalah cara kerja yang teratur, terpikir secara baik, dan bersistem untuk memudahkan pelaksanaan suatu kegiatan guna mencapai tujuan yang telah ditentukan (Djajasudarma, 1993a:1). Jadi, pemilihan metode yang tepat dalam suatu kegiatan dapat memaksimalkan pencapaian tujuan. Metode penelitian merupakan alat, prosedur, dan teknik yang dipilih dalam melaksanakan penelitian. (Djajasudarma, 1993a: 3).

Dalam pengumpulan data digunakan metode dokumentasi. Metode dokumentasi dengan teknik dasar observasi (pengamatan), dan teknik lanjutan berupa pencatatan secara deskriptif terhadap kalimat-kalimat yang mempunyai klausa yang berfungsi sebagai objek pada kartu yang digunakan untuk mengumpulkan data dari sumber tertulis tersebut. Teknik ini oleh Sudaryanto (1991) disebut teknik sitat (observasi-mencatat). Data yang diperoleh dalam bentuk kalimat-kalimat yang diperkirakan mengandung unsur-unsur yang dicari melalui dokumentasi tersebut selanjutnya dicatat pada kartu-kartu yang sudah dipersiapkan untuk dianalisis.

Data yang telah dikumpulkan melalui metode dokumentasi, selanjutnya dianalisis dengan metode distribusional. Analisis distribusional dipahami sebagai analisis yang unsur-unsur penentunya terdapat dalam bahasa itu sendiri (Djajasudarma, 1993:60). Penggunaan metode ini didasarkan pada pertimbangan bahwa setiap unsur bahasa berhubungan satu sama lain yang membentuk satu kesatuan yang padu (de Sausure, 1916 dalam Djajasudarma, 1993a:60).

Teknik analisis distribusional antara lain dapat berupa: penyulihan (substitusi), penyisipan (interupsi), perluasan (ekspansi), pemindahan unsur (permutasi), pengulangan unsur (repetisi), parafrase, dan pelesapan (delesi) (Djajasudarma, 1993a:62). Teknik yang dipakai dalam penelitian ini adalah, teknik sulih (substitusi), sisip (interupsi), pindah unsur (permutasi), dan lesap (delesi)

Penelitian ini pada dasarnya menggunakan metode deskriptif-sinkronis. Deskriptif maksudnya, penelitian yang dilakukan semata-mata hanya berdasarkan fakta kebahasaan yang ada atau fenomena yang memang secara empiris hidup pada penuturnya. Dengan demikian, data yang dihasilkan berupa deskripsi yang tidak mempertimbangkan benar salahnya penggunaan bahasa oleh penuturnya, dalam hal ini bahasa Indonesia, (lihat Sudaryanto, 1992: 62). Metode ini lebih menekankan kualitas ciri-ciri data alami yang sesuai dengan pemahaman deskriptif dan alamiah itu sendiri sehingga diperoleh data yang akurat dan bersifat alamiah. (Djajasudarma, 1993a: 8-13; Moleong 1997: 5-6). Sinkronis maksudnya, data 
bahasa yang digunakan diperoleh dalam kurun waktu tertentu yaitu data bahasa pada saat penelitian ini dilaksanakan.

\section{HASIL DAN PEMBAHASAN}

Dalam penelitian ini, penulis menggunakan beberapa teori yang dikemukakan oleh beberapa ahli bahasa dengan menerapkan pendekatan eklektis. Pendekatan eklektis ini dipilih karena tidak ada satu teori yang benar-benar refresentatif untuk menganalisis data dalam penelitian bahasa. Untuk itu, penulis mengambil langkah dengan mempertimbangkan sejumlah teori yang diambil dari beberapa sumber. Konjungsi dalam penelitian ini terdiri atas konjungsi monomorfemis dan polimorfemis. Lebih jelasnya dapat diperhatikan pembahasan berikut.

\section{Konjungsi Monomorfemis}

Jenis konjungsi yang berupa monomorfemis ditemukan dalam penelitian ini berjumlah 118 data yang terdiri atas 9 jenis konjungsi, yakni bahwa, bagaimana(kah), mengapa, apakah, kapan, betapa, agar, supaya, dan untuk. Konjungsi yang menyertai klausa objek tersebut adalah sebagai berikut.

\section{Konjungsi bahwa}

Dalam pemakaian bahasa tulisan ilmiah, seorang penutur lebih sering menggunakan kalimat deklaratif apabila dibandingkan dengan kalimat interogatif, imperatif, dan eksklamatif sehingga konjungsi bahwa paling banyak digunakan oleh seorang penutur dalam konstruksi subordinatif yang menggunakan verba aktif transitif untuk menghubungkan klausa utama dengan klausa subordinatif. Kemungkinan itu menjadi penyebab, mengapa konjungsi bahwa lebih banyak ditemukan dalam data tulis ilmiah ini apabila dibandingkan dengan konjungsi yang menggunakan kata tanya, agar, untuk, betapa, dsb. Data tersebut dapat dikemukakan antara lain sebagai berikut :

1. Samsuri mengatakan bahwa pronomina persona dapat diuraikan dari segi macam dan jumlahnya.

2. Mereka menyadari bahwa mereka telah menaiki tangga yang salah setelah mereka mencapai puncak.

3. Leech dan Svartvik menyebutkan bahwa keterangan adalah unsur tambahan (modifying element).

4. Penelitian ini mempertimbangkan bahwa teknik analisis statistik inferensial tersebut dapat menguji hipotesis penelitian.

Klausa objek ini memakai konjungsi bahwa sebagai penghubung klausa utama dengan klausa subordinatif. Klausa objek yang berkonjungsi bahwa tersebut berada setelah verba aktif transitif mengatakan, menyadari dan mempertimbangkan merupakan nomina deverbal, sedangkan menyebutkan merupakan verbal yang berasal dari verba sebut. Jenis klausa objek tersebut adalah klausa nominal yang berupa klausa deklaratif.

Secara sintaktis, konjungsi bahwa pada kalimat tersebut kehadirannya bersifat longgar sehingga posisinya bisa dipermutasikan ke awal kalimat. Namun, konjungsi 
bahwa pada kalimat tersebut tidak bisa dilesapkan karena kehadirannya bersifat wajib. Untuk menguji bahwa klausa tersebut berfungsi sebagai $O$ adalah dengan teknik sulih (substitusi), yakni klausa objek berpotensi untuk disulih oleh klitik nya, N sesuatu, dan FN hal ini atau hal itu. Di samping itu, klausa objek tersebut bisa juga di analisis dengan teknik lesap, yakni apabila klausa pada kalimat tersebut dilesapkan, strukturnya tidak gramatikal, karena didahului oleh verba aktif transitif, misalnya *Samsuri mengatakan.

\section{Konjungsi bagaimana(kah)}

Klausa objek berkonjungsi bagaimana setelah verba aktif transitif (Aktr) ditemukan 9 buah data. Data tersebut antara lain sebagai berikut.

1. Umumnya semua orang memunculkan bagaimana irama bergilir gelombang beta kemudian diikuti oleh gelombang alpha.

2. Peneliti akan mengkaji bagaimana status identitas peran jender mahasiswi olahraga tersebut diharapkan tetap eksis dalam dunianya.

3. Dengan ini, kita dapat mengetahui bagaimana pewatas nomina itu digunakan dalam bahasa.

4. PT. Ewindo selalu memperhatikan bagaimana perusahaan tersebut mengoptimalkan cara kerja produksinya.

Klausa objek ini memakai konjungsi bagaimana sebagai penghubung klausa utama dengan klausa subordinatif. Klausa objek yang berkonjungsi bagaimana(kah) tersebut berada setelah verba aktif transitif memunculkan, mengkaji, dan mengetahui merupakan verbal yang berasal dari verba muncul, sedangkan verba memperhatikan merupakan nomina deverbal. Jenis klausa objek tersebut adalah klausa nominal yang berupa klausa interogatif.

Secara sintaktis, konjungsi bagaimana pada kalimat tersebut kehadirannya bersifat longgar sehingga posisinya bisa dipermutasikan ke awal kalimat. Namun, konjungsi bagaimana pada kalimat tersebut tidak bisa dilesapkan karena kehadirannya bersifat wajib.

\section{Konjungsi mengapa} berikut.

Konjungsi mengapa ditemukan satu data. Lebih jelasnya, perhatikan kalimat

Ia bisa memikirkan mengapa volume mahkota emas itu setelah dimasukkan ke dalam air dapat diketahui beratnya.

Klausa objek ini memakai konjungsi mengapa sebagai penghubung klausa utama dengan klausa subordinatif. Klausa objek yang berkonjungsi tersebut berada setelah verba aktif transitif memikirkan merupakan nomina deverbal. Jenis klausa objek tersebut adalah klausa nominal yang berupa klausa interogatif.

Secara sintaktis, konjungsi mengapa pada kalimat tersebut kehadirannya bersifat longgar karena posisinya bisa dipermutasikan ke awal kalimat. Di samping itu, konjungsi apakah pada kalimat tersebut tidak bisa dilesapkan karena 
kehadirannya bersifat wajib. Namun, konjungsi mengapa pada kalimat tersebut bisa disubstitusi dengan sejak kapan dan bagaimana.

\section{Konjungsi apakah}

Klausa objek berkonjungsi apakah setelah verba aktif ini ditemukan 3 buah data. Perhatikan data berikut.

1. Mereka mempersoalkan apakah gangguan fonologis seperti agramatisme adalah gangguan yang jelas dan nyata pada afasia.

2. Secara perlahan, individu menentukan apakah peran itu sesuai atau tidak sesuai dengan jati dirinya.

3. Dia menerangkan apakah suatu pekerjaan, peristiwa, keadaan, atau sifat itu sedang berlangsung (perfektif), belum selesai (inperfektif), atau mulai berlangsung (inkoatif).

Klausa objek ini memakai konjungsi apakah sebagai penghubung klausa utama dengan klausa subordinatif. Klausa objek yang berkonjungsi tersebut berada setelah verba aktif transitif mempersoalkan merupakan nomina deverbal, sedangkan verba menentukan, dan menerangkan merupakan ajektiva deverbal. Jenis klausa objek tersebut adalah klausa nominal yang berupa klausa interogatif.

Secara sintaktis, konjungsi apakah pada kalimat tersebut kehadirannya bersifat longgar sehingga posisinya bisa dipermutasikan ke awal kalimat. Namun, konjungsi apakah pada kalimat tersebut tidak bisa dilesapkan karena kehadirannya bersifat wajib.

\section{Konjungsi kapan}

Klausa objek berkonjungsi kapan setelah verba Aktif transitif ini ditemukan 3 buah data, Data tersebut antara lain sebagai berikut :

1. Ani menanyakan kepada saya kapan kita akan berkumpul lagi.

2. Dia sudah mengetahui kapan kita akan pergi kerumahnya.

3. Saya tidak memperhatikan kapan dia menemui orang itu.

Klausa objek ini memakai konjungsi kapan sebagai penghubung klausa utama dengan klausa subordinatif. Klausa objek yang berkonjungsi tersebut berada setelah verba aktif transitif menanyakan dan mengetahui yang merupakan verba deverbal, sedangkan verba memperhatikan merupakan nomina deverbal. Jenis klausa objek tersebut adalah klausa nominal yang berupa klausa interogatif.

Secara sintaktis, konjungsi kapan pada kalimat tersebut kehadirannya bersifat longgar sehingga posisinya bisa dipermutasikan ke awal kalimat. Namun, konjungsi kapan pada kalimat tersebut tidak bisa dilesapkan karena kehadirannya bersifat wajib. 


\section{Konjungsi agar}

Klausa objek berkonjungsi agar setelah verba Aktr ini ditemukan 3. Perhatikan data berikut.

1. Saya menganjurkan agar mereka membuat rencana perbaikan di tingkat pelayanan.

2. Friedan menyarankan agar wanita mengadakan identifikasi diri supaya beralih dari ketidakdewasaan yang disebut feminisitas kearah identitas manusia seutuhnya.

3. Mahasiswi menginginkan agar berbagai alternatif pilihan tersebut dapat dipertimbangkan oleh mereka dalam mengadopsi peran jender.

Klausa objek ini memakai konjungsi agar sebagai penghubung klausa utama dengan klausa subordinatif. Klausa objek yang berkonjungsi tersebut berada setelah verba aktif transitif, menyarankan merupakan nomina deverbal, sedangkan menganjurkan merupakan verba deverbal dan menginginkan merupakan adverbia deverbal. Jenis klausa objek tersebut adalah klausa nominal yang berupa klausa imperatif.

Secara sintaktis, konjungsi agar pada kalimat tersebut kehadirannya bersifat longgar sehingga posisinya bisa dipermutasikan ke awal kalimat. Namun, konjungsi agar pada kalimat tersebut bisa disubstitusi dengan onjungsi supaya.

\section{Konjungsi supaya}

Klausa objek berkonjungsi supaya setelah verba aktif transitif ini ditemukan 2 buah data. Perhatikan data berikut.

1. Saya meminta supaya dia belajar setiap hari di rumah.

2. Pak wawan memerintahkan supaya menejer pembeliannya membeli cermin dinding untuk ruang operator.

Klausa objek ini memakai konjungsi supaya sebagai penghubung klausa utama dengan klausa subordinatif. Klausa objek yang berkonjungsi tersebut berada setelah verba aktif transitif meminta yang merupakan verba deverbal dan verba memerintahkan merupakan nomina deverbal. Jenis klausa objek tersebut adalah klausa nominal yang berupa klausa imperatif.

Secara sintaktis, konjungsi supaya pada kalimat tersebut kehadirannya bersifat longgar sehingga posisinya bisa dipermutasikan ke awal kalimat. Namun, konjungsi supaya pada kalimat tersebut bisa disubstitusi dengan konjungsi agar.

\section{Konjungsi betapa}

Klausa objek berkonjungsi betapa setelah verba Aktif transitif (Aktr) ini terdapat dua buah data. Data tersebut sebagai berikut.

1. Kita sudah melihat betapa manusia selalu berusaha 
2. Kita merasakan betapa sulitnya mereka memahami dasar individual dan ekspresinya terhadap keadaan sosial.

Klausa objek ini memakai konjungsi betapa sebagai penghubung klausa utama dengan klausa subordinatif. Klausa objek yang berkonjungsi tersebut berada setelah verba aktif transitif melihat yang merupakan verba deverbal (verba lihat menjadi verbal melihat). sedangkan merasakan merupakan nomina deverbal. Jenis klausa objek tersebut adalah klausa nominal yang berupa klausa eksklamatif.

Secara sintaktis, konjungsi betapa pada kalimat tersebut kehadirannya bersifat longgar sehingga posisinya bisa dipermutasikan ke awal kalimat. Namun, konjungsi betapa pada kalimat tersebut tidak bisa dilesapkan karena kehadirannya bersifat wajib.

\section{Konjungsi untuk}

Klausa objek berkonjungsi untuk setelah verba Aktr ini terdapat empat 4 data. Perhatikan data berikut.

1. Saya akan mencoba untuk memberikan beberapa contoh sikap yang bijaksana.

2. Hal ini akan membantu untuk menerjemahkan Asmaul Husna ke dalam keseharian.

3. Yani telah memutuskan untuk mengakhiri hubungannya dengan Rudi.

4. Penggunaan sistem pencatatan ini dapat memudahkan untuk mengendalikan perusahaan.

Klausa objek ini memakai konjungsi untuk sebagai penghubung klausa utama dengan klausa subordinatif. Klausa objek yang berkonjungsi tersebut berada setelah verba aktif transitif mencoba, membantu, memutuskan yang merupakan verba deverbal, sedangkan verba memudahkan merupakan ajektiva deverbal. Jenis klausa objek tersebut adalah klausa objek yang berupa klausa deklaratif.

Secara sintaktis, konjungsi untuk pada kalimat tersebut kehadirannya bersifat longgar sehingga posisinya bisa dipermutasikan ke awal kalimat. Namun, konjungsi untuk pada kalimat tersebut tidak bisa dilesapkan karena kehadirannya bersifat wajib.

\section{Konjungsi Polimorfemis}

Jenis konjungsi berupa polimorfemis yang terdapat dalam data berjumlah 14 jenis, yakni ke mana, sejauh mana, kepada siapa, di mana, dari mana, untuk apa, untuk siapa, dengan apa, dengan siapa, sejak kapan, waktu apa, sambil apa, sehabis apa, dan berapa lama. Lebih jelasnya, perhatikan uraian berikut.

\section{Konjungsi ke mana}

Konjungsi berkonjungsi ke mana setelah verba Aktr pada penelitian ini ditemukan satu buah data. Perhatikan data berikut. 
Mahasiswi tersebut selalu menanyakan ke mana individu bisa menuntun arah yang diinginkannya.

Klausa objek berkonjungsi kata tanya ini memakai konjungsi ke mana untuk menghubungkan klausa utama dengan klausa subordinatif. Klausa objek yang berkonjungsi tersebut berada setelah verba meN-tanya-kan yang merupakan nomina deverbal. Jenis klausa objek setelah konjungsi tersebut adalah klausa nominal yang berupa klausa interogatif.

Secara sintaktis, konjungsi ke mana pada kalimat tersebut kehadirannya bersifat longgar sehingga posisinya bisa dipermutasikan ke awal kalimat. Namun, konjungsi ke mana pada kalimat tersebut tidak bisa dilesapkan karena kehadirannya bersifat wajib.

\section{Konjungsi sejauh mana}

Klausa berkonjungsi sejauh mana setelah verba Aktif transitif dalam penelitian ini ditemukan satu data. Perhatikan data berikut.

Mahasiswa dapat mengetahui sejauh mana dosen memberikan kesempatan kepada dirinya untuk melakukan eksplorasi dan komitmen dalam peran jender.

Klausa objek berkonjungsi kata tanya ini memakai konjungsi sejauh mana untuk menghubungkan klausa utama dengan klausa subordinatif. Klausa objek yang berkonjungsi tersebut berada setelah verba mengetahui yang merupakan verba deverbal. Jenis klausa objek setelah konjungsi tersebut adalah klausa nominal yang berupa klausa interogatif.

Secara sintaktis, konjungsi sejauh mana pada kalimat tersebut kehadirannya bersifat longgar sehingga posisinya bisa dipermutasikan ke awal kalimat. Namun, konjungsi sejauh mana pada kalimat tersebut tidak bisa dilesapkan karena kehadirannya bersifat wajib.

\section{Konjungsi kepada siapa}

Klausa objek berkonjungsi kepada siapa terdapat 4 buah data. Data tersebut sebagai berikut.

1. Dia belum memberitahukan kepada siapa dia memberikan uang itu.

2. Anak itu selalu menanyakan kepada siapa dia bisa mengadukan nasibnya

3. Saya belum mengetahui kepada siapa mereka menyampaikan aspirasinya.

4. Saya tidak memperhatikan kepada siapa orang itu melampiaskan kemarahannya

Klausa objek ini memakai konjungsi kepada siapa untuk menghubungkan klausa utama dengan klausa subordinatif. Klausa objek yang berkonjungsi tersebut berada setelah verba aktif transitif mengetahui, memberitahukan, menanyakan yang merupakan verba deverbal, yakni meN-kan + verba. Sedangkan verba memperhatikan, terdiri atas memper-kan + nomina hati yang merupakan nomina 
deverbal. Jenis klausa objek tersebut adalah klausa nominal yang berupa klausa interogatif.

Secara sintaktis, konjungsi kepada siapa pada kalimat tersebut kehadirannya bersifat longgar sehingga posisinya bisa dipermutasikan ke awal kalimat. Namun, konjungsi kepada siapa pada kalimat tersebut tidak bisa dilesapkan karena kehadirannya bersifat wajib.

\section{Konjungsi di mana}

Klausa objek berkonjungsi di mana setelah verba Aktr ini terdapat 4 buah data. Konjungsi di mana adalah untuk menanyakan tempat berada. Perhatikan data berikut.

1. Anak itu telah mengatakan di mana dia menyembunyikan dompet itu.

2. Pimpinan menanyakan tadi di mana data itu dapat kita temukan.

3. Para teroris itu telah mengakui di mana mereka meletakkan bom itu.

4. Bapak menanyakan di mana surat itu dikirim.

Klausa objek pada keempat data ini memakai konjungsi di mana untuk menghubungkan klausa utama dengan klausa subordinatif. Klausa objek yang berkonjungsi tersebut berada setelah verba mengatakan, mengakui dan menanyakan merupakan nomina deverbal. Jenis klausa objek setelah konjungsi tersebut adalah klausa nominal yang berupa klausa interogatif.

Secara sintaktis, konjungsi di mana pada kalimat tersebut kehadirannya bersifat longgar sehingga posisinya bisa dipermutasikan ke awal kalimat. Namun, konjungsi di mana pada kalimat tersebut tidak bisa dilesapkan karena kehadirannya bersifat wajib.

\section{Konjungsi dari mana}

Klausa objek berkonjungsi dari mana setelah verba Aktr ini terdapat 4 data. Perhatikan data berikut.

1. Kami sudah mengetahui dari mana orang itu datang.

2. Bu Ani belum menyebutkan dari mana kita mulai mengerjakan $P R$ ini.

3. Bu Ani tidak mempersoalkan dari mana mereka mendapatkan buku itu.

4. Mereka belum menjelaskan dari mana mereka mulai membahas hal tersebut.

Klausa objek pada data di atas memakai konjungsi dari mana untuk menghubungkan klausa utama dengan klausa subordinatif. Klausa objek yang berkonjungsi tersebut berada setelah verba mengetahui, meyebutkan, yang merupakan verba deverbal; verba mempersoalkan merupakan nomina deverbal, sedangkan verba menjelaskan merupakan ajektiva deverbal. Jenis klausa objek setelah konjungsi tersebut adalah klausa nominal yang berupa klausa interogatif.

Secara sintaktis, konjungsi dari mana pada kalimat tersebut kehadirannya bersifat longgar sehingga posisinya bisa dipermutasikan ke awal kalimat. Namun, konjungsi dari mana pada kalimat tersebut tidak bisa dilesapkan karena kehadirannya bersifat wajib. 


\section{Konjungsi untuk apa}

Klausa objek berkonjungsi untuk apa setelah verba Aktr dalam penelitian ini terdapat 4 data, yakni data lampiran (131 - 134). Data tersebut sebagai berikut.

1. Dia belum mengatakan untuk apa dia mengadakan pertemuan itu.

2. Saya akan menjelaskan untuk apa penelitian ini dilakukan.

3. Bapak sudah mengingatkan kemarin untuk apa mereka datang ke tempat terlarang itu.

4. Dia menanyakan untuk apa saya memanggil tukang becak itu.

Klausa objek pada data di atas memakai konjungsi untuk apa sebagai penghubung klausa utama dengan klausa subordinatif. Klausa objek yang berkonjungsi tersebut berada setelah verba mengatakan merupakan nomina deverbal; menjelaskan merupakan ajektiva deverbal; dan menanyakan, mengingatkan merupakan verba deverbal. Jenis klausa objek setelah konjungsi tersebut adalah klausa nominal yang berupa klausa interogatif.

Secara sintaktis, konjungsi untuk apa pada kalimat tersebut kehadirannya bersifat longgar sehingga posisinya bisa dipermutasikan ke awal kalimat. Namun, konjungsi untuk apa pada kalimat tersebut tidak bisa dilesapkan karena kehadirannya bersifat wajib.

\section{Konjungsi untuk siapa}

Klausa objek berkonjungsi untuk siapa setelah verba Aktr dalam penelitian ini terdapat 4 data. Data tersebut sebagai berikut.

1. Adik menanyakan untuk siapa sepatu ini dibeli.

2. Orang itu sudah memberitahukan untuk siapa mereka melakukan hal itu.

3. Dia belum menyebutkan untuk siapa baju ini dijahit.

4. Saya tidak mempersoalkan untuk siapa ia membuat ramuan ini

Klausa objek pada data di atas memakai konjungsi untuk siapa sebagai penghubung klausa utama dengan klausa subordinatif. Klausa objek yang berkonjungsi tersebut berada setelah verba menanyakan, menyebutkan, memberitahukan, merupakan verba deverbal, sedangkan verba mempersoalkan merupakan nomina deverbal. Jenis klausa objek setelah konjungsi tersebut adalah klausa nominal yang berupa klausa interogatif.

Secara sintaktis, konjungsi untuk siapa pada kalimat tersebut kehadirannya bersifat longgar sehingga posisinya bisa dipermutasikan ke awal kalimat. Namun, konjungsi untuk siapa pada kalimat tersebut tidak bisa dilesapkan karena kehadirannya bersifat wajib.

\section{Konjungsi dengan siapa}

Klausa objek berkonjungsi dengan siapa setelah verba Aktr dalam penelitian ini terdapat 4 data. Data tersebut sebagai berikut. 
1. Dia menanyakan dengan siapa ia pergi ke Jakarta besok.

2. Dia sudah memberitahukan dengan siapa dia mengerjakan tugas itu.

3. Saya tidak memperhatikan dengan siapa orang itu datang ke sini.

4. Bapak menanyakan dengan siapa mereka pergi ke Bali.

Klausa objek pada data di atas memakai konjungsi dengan siapa sebagai penghubung klausa utama dengan klausa subordinatif. Klausa objek yang berkonjungsi tersebut berada setelah verba menanyakan, memberitahukan, merupakan verba deverbal, sedangkan verba memperhatikan merupakan nomina deverbal. Jenis klausa objek setelah konjungsi tersebut adalah klausa nominal yang berupa klausa interogatif.

Secara sintaktis, konjungsi dengan siapa pada kalimat tersebut kehadirannya bersifat longgar sehingga posisinya bisa dipermutasikan ke awal kalimat. Namun, konjungsi dengan siapa pada kalimat tersebut tidak bisa dilesapkan karena kehadirannya bersifat wajib.

\section{Konjungsi dengan apa}

Klausa objek berkonjungsi dengan apa setelah verba Aktr dalam penelitian ini terdapat 4 data. Data tersebut sebagai berikut.

1. Saya sudah melihat dengan apa dia membawa tas yang berat itu.

2. Saya tidak mengetahui dengan apa mereka membuka pintu itu.

3. Dia menanyakan dengan apa saya berangkat ke Jakarta.

4. Saya menyangsikan dengan apa dia bisa membalas jasanya.

Klausa objek pada data ini memakai konjungsi dengan apa sebagai penghubung klausa utama dengan klausa subordinatif. Klausa objek yang berkonjungsi tersebut berada setelah verba melihat, mengetahui, dan menanyakan, merupakan verba deverbal, sedangkan menyangsikan merupakan ajektiva deverbal. Jenis klausa objek setelah konjungsi tersebut adalah klausa nominal yang berupa klausa interogatif.

Secara sintaktis, konjungsi dengan apa pada kalimat tersebut kehadirannya bersifat longgar sehingga posisinya bisa dipermutasikan ke awal kalimat. Namun, konjungsi dengan apa pada kalimat tersebut tidak bisa dilesapkan karena kehadirannya bersifat wajib.

\section{Konjungsi sejak kapan}

Klausa objek berkonjungsi sejak kapan setelah verba aktif transitif dalam penelitian ini terdapat 4 data. Data tersebut sebagai berikut.

1. Saya tidak menyadari sejak kapan dia memperhatikan saya.

2. Saya tidak memperhatikan sejak kapan dia berdiri di situ.

3. Bapak tidak mengetahui sejak kapan rumah itu di bakar.

4. Saya tidak menyangka sejak kapan dia bisa berubah. 
Klausa objek pada data ini memakai konjungsi sejak kapan sebagai penghubung klausa utama dengan klausa subordinatif. Klausa objek yang berkonjungsi tersebut berada setelah verba menyadari dan memperhatikan merupakan nomina deverbal, sedangkan mengetahui, menyangka, merupakan verba deverbal. Jenis klausa objek setelah konjungsi tersebut adalah klausa nominal yang berupa klausa interogatif.

Secara sintaktis, konjungsi sejak kapan pada kalimat tersebut kehadirannya bersifat longgar sehingga posisinya bisa dipermutasikan ke awal kalimat. Namun, konjungsi sejaka kapan pada kalimat tersebut tidak bisa dilesapkan karena kehadirannya bersifat wajib.

\section{Konjungsi waktu apa}

Klausa objek berkonjungsi waktu apa setelah verba Aktr dalam penelitian ini terdapat 4 data. Data tersebut sebagai berikut.

1. Dia menanyakan waktu apa kita bisa datang ke rumahnya.

2. Dia dapat menentukan waktu apa kita melaksanakan shalat subuh.

3. Dia tidak menyadari waktu apa dosen memberikan kesempatan pada dirinya.

4. Mereka menanyakan waktu apa kita bisa berdiskusi lagi.

Klausa objek pada data di atas memakai konjungsi waktu apa sebagai penghubung klausa utama dengan klausa subordinatif. Klausa objek yang berkonjungsi tersebut berada setelah verba menanyakan merupakan nomina deverbal, sedangkan menentukan dan menyadari merupakan ajektiva deverbal. Jenis klausa objek setelah konjungsi tersebut adalah klausa nominal yang berupa klausa interogatif.

Secara sintaktis, konjungsi waktu apa pada kalimat tersebut kehadirannya bersifat longgar sehingga posisinya bisa dipermutasikan ke awal kalimat. Namun, konjungsi waktu apa pada kalimat tersebut bisa disubstitusikan dengan konjungsi kapan dan untuk apa.

\section{Konjungsi sambil apa}

Klausa objek berkonjungsi sambil apa setelah verba Aktr dalam penelitian ini terdapat 4 data. Data tersebut sebagai berikut.

1. Dia sudah menerangkan sambil apa kita bisa mengerjakan itu.

2. Mereka memberitahukan sambil apa kita bisa mengisi waktu kita.

3. Susi menanyakan sambil apa bapak mencuci mobil.

4. Dia mengatakan sambil apa dia membaca buku itu.

Klausa objek pada data di atas memakai konjungsi sambil apa sebagai penghubung klausa utama dengan klausa subordinatif. Klausa objek yang berkonjungsi tersebut berada setelah verba menerangkan merupakan ajektiva deverbal, sedangkan memberitahukan merupakan verba deverbal: menanyakan 
dan mengatakan merupakan nomina deverbal. Jenis klausa objek setelah konjungsi tersebut adalah klausa nominal yang berupa klausa interogatif.

Secara sintaktis, konjungsi sambil apa pada kalimat tersebut kehadirannya bersifat longgar sehingga posisinya bisa dipermutasikan ke awal kalimat. Namun, konjungsi sambil apa pada kalimat tersebut tidak bisa dilesapkan karena kehadirannya bersifat wajib.

\section{Konjungsi sehabis apa}

Klausa objek berkonjungsi sehabis apa setelah verba Aktif transitif dalam penelitian ini terdapat 4 data, yakni data lampiran (159 - 162). Data tersebut sebagai berikut.

1. Ani menanyakan kemarin sehabis apa kita bisa berdiskusi.

2. Dia telah mengatakan sehabis apa kita akan makan bersama-sama.

3. Dia belum menyebutkan sehabis apa kita akan menjenguk teman yang sakit.

4. Dia telah menceritakan sehabis apa dia menemui gadis itu.

Klausa objek pada data di atas memakai konjungsi sehabis apa sebagai penghubung klausa utama dengan klausa subordinatif. Klausa objek yang berkonjungsi tersebut berada setelah verba menanyakan, mengatakan, dan menceritakan merupakan nomina deverbal, sedangkan menyebutkan merupakan verba deverbal. Jenis klausa objek setelah konjungsi tersebut adalah klausa nominal yang berupa klausa interogatif.

Secara sintaktis, konjungsi sehabis apa pada kalimat tersebut kehadirannya bersifat longgar sehingga posisinya bisa dipermutasikan ke awal kalimat. Namun, konjungsi sehabis apa pada kalimat tersebut tidak bisa dilesapkan karena kehadirannya bersifat wajib.

\section{Konjungsi berapa lama}

Klausa objek berkonjungsi berapa lama setelah verba Aktr dalam penelitian ini terdapat 4 data. Data tersebut sebagai berikut.

1. Mereka menanyakan tadi berapa lama kita akan tidur di sini.

2. Dia telah membuktikan berapa lama ia sanggup menyelam.

3. Dia belum menerangkan berapa lama sebuah reaksi akan menciptakan reaksi.

4. Ia telah merasakan berapa lama ia menaggung beban itu.

Klausa objek pada data di atas memakai konjungsi berapa lama sebagai penghubung klausa utama dengan klausa subordinatif. Klausa objek yang berkonjungsi tersebut berada setelah verba menanyakan, merasakan dan membuktikan merupakan nomina deverbal, sedangkan menerangkan merupakan ajektiva deverbal. Jenis klausa objek setelah konjungsi tersebut adalah klausa nominal yang berupa klausa interogatif.

Secara sintaktis, konjungsi berapa lama pada kalimat tersebut kehadirannya bersifat longgar sehingga posisinya bisa dipermutasikan ke awal kalimat. Namun, 
konjungsi berapa lama pada kalimat tersebut tidak bisa dilesapkan karena kehadirannya bersifat wajib.

\section{SIMPULAN}

Penelitian ini merupakan upaya untuk memperkuat, melengkapi, dan mengembangkan teori yang sudah ada sehubungan dengan klausa objek dalam bahasa Indonesia. Temuan-temuan pada penelitian ini merupakan sumbangan bagi perkembangan linguistik, khususnya yang berhubungan dengan klausa objek dalam bahasa Indonesia baik dari segi struktur maupun semantik.

Penelitian ini menemukan klausa objek yang berkonjungsi dan klausa objek yang tidak berkonjungsi. Konjungsi yang menyertai klausa objek tersebut ada yang monomorfemis dan ada pula polimorfemis. Konjungsi tersebut sebagai berikut.
a. Monomorfemis : bahwa, bagaimana, mengapa, apakah, kapan, agar, supaya, betapa, dan untuk.
b. Polimorfemis : $\quad$ ke mana, sejauh mana, kepada siapa, di mana, dari mana, untuk apa, untuk siapa, dengan siapa, dengan apa, sejak kapan, waktu apa, sambil apa, sehabis apa, dan berapa lama.

\section{UCAPAN TERIMA KASIH}

Pada kesempatan ini, penulis mengucapkan terimakasih kepada Prof. Moh. Tadjuddin, Prof. Fatimah Djajasudarma, Prof. J. S. Badudu, Prof. Dudih A. Zuhud, Dr. Wahya, Dr. Cece Sobarna, dan Dr. Herianto yang telah memberikan masukan dalam penelitian ini. Semoga bapak/Ibu selalu diberkati Allah subhanahuwataala, Amiin.

\section{DAFTAR PUSTAKA}

Alisjahbana, Sutan Takdir. 1981. Tatabahasa Baru Bahasa Indonesia. Jakarta: Dian Rakyat.

Alwi, Hasan, dkk. 1988. Bahasa Baku Bahasa Indonesia. Jakarta: Balai Pustaka.

Bloomfield, Leonard. 1933. Language. New York: Henry Holt and Company.

Chaer, Abdul. 1990. Penggunaan Preposisi dan Konjungsi Bahasa Indonesia. Ende, Flores: Penerbit Nusa Indah

Djajasudarma, T. Fatimah. 1993a Metode Linguistik: Ancangan Metode Penelitian dan Kajian. Bandung: PT.Eresco.

Bandung. P.T Eresco.

1993b Semantik 1 dan 2: Pemahaman Ilmu Makna.

1999 Analisis Bahasa Sintaksis dan Semantik.

Bandung. Humaniora Utama Press. 
Gianto, AG. 1983. Konjungsi 'dan',' atau', 'tetapi': Kajian Sintaksis. Yogyakarta: Yayasan Kanisius.

Givon, Talmy. 1983. Syntax: A Functional Typological Introduction. Vol.1 Philadelphia: john Benjamin's Publishing Copany.

Gleitmann, Lila R. 1965. Coordinating Grammer. New York, Sanfransisco, London: Academic Press.

Hadiwidhaya. 1965. Tatabahasa Indonesia. Yogyakarta: UP Indonesia.

Hockett, Charles F.1969. A Course in Modern Linguistics. Toronto: The Macmillan Company.

Keraf, Gorys. 1973. Tata Bahasa Indonesia. Ende, Flores: Nusa Indah.

Kridalaksana, Harimurti, dkk. 1983. Tata Bahasa Deskriptif Bahasa Indonesia: Sintaksis. Jakarta: Pusat Pembinaan dan Pengembangan Bahasa. Departemen Pendidikan dan Kebudayaan.

Kridalaksana, Harimurti. 1986. Kelas Kata dalam Bahasa Indonesia. Jakarta: Gramedia.

. 2002. Struktur, Kategori, dan Fungsi dalam Teori Sintaksis. Jakarta: Perpustakaan Nasional.

Lapoliwa, Hans.1990. Klausa Pemerlengkapan dalam Bahasa Indonesia. Yogyakarta: Kanisius.

Lyons, John. 1977 Semantics 1. Great Britain: Cambridge University Press.

Mess, C.A. 1955. Tatabahasa. Indonesia. Djakarta: J.B. Wolters Groningen.

Moeliono, Anton M. 1988. Tata Bahasa Baku Bahasa Indonesia. Jakarta: Perum Balai Pustaka.

1976. Pedoman Penulisan Tata Bahasa Indonesia.Jakarta: Pusat Pembinaan dan Pengembangan Bahasa.

Moleong, Lexy J. 1997. Metodologi Penelitian Kualitatif. Bandung: Remaja Rosdakarya.

Nardiati, Sri, dkk. 1966. Konjungsi Subordinatif dalam Bahasa Indonesia. Jakarta: Pusat Pembinaan dan Pengembangan Bahasa. 
Ramlan,M. 1980. Kata Depan atau Preposisi dalam Bahasa Indonesia.Yogyakarta: CV Karono Indonesia

Sibarani, Robert. 1994. Konjungsi Bahasa Batak Toba: Sebuah Kajian Struktur dan Semantik. Disertasi. Bandung:Universitas Padjadjaran.

Sobarna, Cece. 2002. "Preposisi Bahasa Sunda Satu Kajian Struktur dan Semantik". Disertasi. Bandung: Universitas Padjadjaran.

Sudaryanto. 1991. Metode Linguistik: Kedudukan, Aneka jenisnya, dan faktor Penentu Wujudnya. Yogyakarta: Fak. Sastra dan Kebudayaan, Universitas Gadjah Mada.

1994. Predikat-Objek dalam Bahasa Indonesia. Keselarasan Pola Urutan Jakarta: Djambatan.

Sugono, Dendy dan Titik Indiyastini. 1994. Verba dan Komplementasinya. Jakarta: Pusat Pembinaan dan Pengembangan Bahasa.

Suhendar, M.E. 1978. Pemakaian Kata Depan dan Kata Sambung dalam Bahasa Indonesia. Bandung: Lingga.

Tadjuddin, Moh, dkk. 2001. Preposisi dan Konjungsi: Studi Tipologi Bahasa SundaBahasa Indonesia. Jakarta: Pusat Bahas

Tadjuddin, Moh. 2005. Konjungsi Subordinatif Aspektualitas dan Temporalitas dalam Bahasa Indonesia. dalam Aspektualitas dalam Kajian Linguistik. Bandung: P.T. Alumni Bandung. 